\title{
Penerapan Dynamic System Development Method Pada Sistem Monitoring Status Gizi Balita
}

\author{
Tumini $^{1}$, Sugiyanti ${ }^{2}$ \\ ${ }^{1,2}$ STMIK Cikarang, Jl. Kapten Sumantri No 16 Cikarang, kab. Bekasi 17530, Indonesia \\ e-mail: kemuningijo@gmail.com ${ }^{* 1}$,2ugi.sugianti09@gmail.com ${ }^{2}$
}

\begin{tabular}{|c|c|}
\hline INFORMASI ARTIKEL & A B S T R A $K$ \\
\hline $\begin{array}{l}\text { Sejarah Artikel: } \\
\text { Diterima Redaksi : } 16 \text { April } 2020 \\
\text { Revisi Akhir : } 18 \text { Mei } 2020 \\
\text { Diterbitkan Online : } 30 \text { Mei } 2020\end{array}$ & $\begin{array}{l}\text { Kondisi gizi pada balita sangat penting untuk diperhatikan oleh para orang tua. Agar para orang tua } \\
\text { dapat mengetahui pertumbuhan tubuh serta kondisi gizi balita dan mencegah resiko yang } \\
\text { memungkinkan terjadi jika balita mengalami ganguan terhadap gizinya terutama di Posyandu Seruni } \\
\text { 11. Pentingnya orang tua mengetahui status gizi balita dengan mudah maka diperlukan suatu sistem } \\
\text { yang mudah di akses untuk mengetahui status gizi balita. Maka tujuan penelitian ini adalah membuat } \\
\text { suatu sistem menggunakan metode Dynamic System Development Method (DSDM) dan framework }\end{array}$ \\
\hline $\begin{array}{l}\text { Kata Kunci: } \\
\text { CodeIgniter, DSDM, Gizi Balita }\end{array}$ & $\begin{array}{l}\text { CodeIgniter yang memudahkan petugas ataupun orang tua untuk mengetahui status gizi balita dengan } \\
\text { cepat dan mudah di akses. Pengimplementasian sistem dibagi untuk bagian admin atau petugas dari }\end{array}$ \\
\hline $\begin{array}{l}\text { Korespondensi : } \\
\text { Telepon / Hp : 0812-9982-0469 }\end{array}$ & $\begin{array}{l}\text { didapatkan hasil pengujian berupa nilai } 73,80 \% \text { untuk menu admin dan } 91,51 \% \text { untuk menu user. } \\
\text { Hasil pengujian tersebut maka dapat disimpulkan bahwa sistem ini layak untuk digunakan. }\end{array}$ \\
\hline
\end{tabular}

E-mail : kemuningijo@gmail.com

\section{PENDAHULUAN}

Gizi merupakan salah satu kebutuhan pokok yang diperlukan dalam proses perkembangan dan pertumbuhan tubuh manusia. Untuk memenuhi kebutuhan dalam proses pertumbuhan perkembangan serta mempertahankan hidup, manusia sangat membutuhkan asupan gizi yang cukup. Pada anak khususnya balita, asupan gizi sangat penting untuk diperhatikan. Jika asupan gizi kurang terpenuhi maka balita akan mengalami gangguan kesehatan serta gangguan pada pertumbuhan tubuhnya. Dalam hal ini orang tua wajib memperhatikan kebutuhan asupan gizi yang cukup agar tidak terjadi masalah pada pertumbuhan tubuh balitanya.

Untuk mengetahui perkembangan dan pertumbuhan tubuh serta kondisi gizi balita salah satunya dengan mengikuti kegiatan posyandu. Posyandu Seruni 11 adalah salah satu posyandu yang berada di desa Karang Raharja kecamatan Cikarang Utara. Kegiatan yang ada dalam posyandu ini mencakup pengecekan berat badan, tinggi badan maupun pemberian vitamin serta imunisasi. Dalam kegiatan posyandu ini petugas mendapatkan data balita serta data hasil penimbangan berat badan balita yang dicatat dibuku laporan petugas sehingga memerlukan waktu dalam pencarian data balita dan dapat menyebabkan mudah hilangnya data. Data berat badan balita juga dijadiakan acuan untuk pengisian Kartu Menuju Sehat (KMS) yang memuat kurva pertumbuhan normal anak berdasarkan indeks antrometri berat badan menurut umur yang diolah secara manual sehingga diperlukan waktu untuk mengetahui status gizinya.

Perkembangan teknologi informasi saat ini yang cukup pesat dapat dimanfaatkan sebagai media pengolah data untuk menghitung dan menentukan status gizi pada balita yang telah ditimbang berat badannya dan telah diketahui umurnya. Dan juga dapat dijadikan sebagai layanan informasi yang lebih tersistem pendataannya agar informasi yang tersampaikan lebih akurat dan lebih mudah untuk diakses oleh masyarakat.

Pada penelitian ini penulis bermaksud merancang suatu sistem yang memberi layanan informasi status gizi pada balita dengan judul "Penerapan Dynamic System Development Method Pada Rancang Bangun Sistem Monitoring Status Gizi Balita Menggunakan Codeigniter". Dengan pengolahan data lebih optimal diharapkan dapat menjadi tolak ukur untuk memantau kesehatan dan pertumbuhan anak selain menggunakan sistem yang saat ini berjalan yaitu Katu Menuju Sehat (KMS) dan juga agar dapat memudahkan masyarakat pengguna layanan posyandu Seruni 11 untuk lebih mudah melihat status gizi pada balitanya.

\section{LANDASAN PUSTAKA}

2.1 DSDM(Dynamic System Development Method) Menurut D. E. Evison dan Fitzgerald, "Dynamic System Development Method (DSDM) merupakan upaya penyempurnaan James Martin Rapid Aplication Development Method (JMRAD). DSDM berusaha memasukkan unsur disiplin ke dalam JMRAD. DSDM dikembangkan oleh konsorsium DSDM di Eropa. Konsorsium DSDM dibentuk tahun 1994 [8]. DSDM mendefinisikan RAD sebagai kerangka kerja (framework) penyelesaian proyek pengembangan sistem informasi RAD membantu pengembangan sistem informasi dan solusi bisnis dalam batasan waktu yang sempit dan anggaran yang terbatas. 


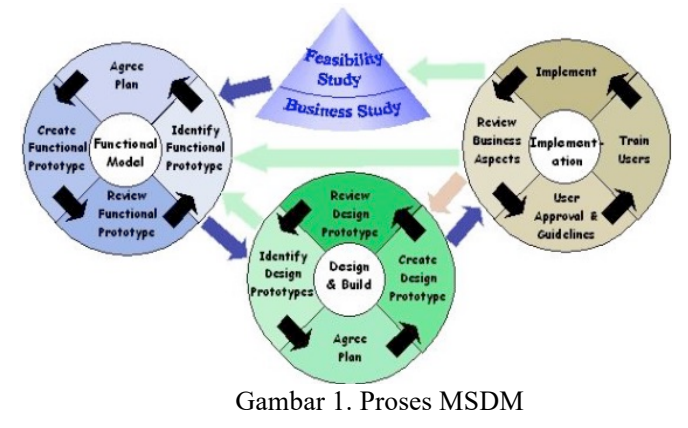

Dalam DSDM terdiri dari 3 tahapan utaman ada $5 \mathrm{sub}$ tahapan yaitu:

1. Sebelum proyek, dimana kandidat proyek diidentifikasi, pembiayaan proyek terpenuhi, dan jaminan proyek dipastikan. Penanganan hal-hal tersebut pada tahap ini menghindari masalah pada tahap-tahap berikutnya.

2. Siklus hidup proyek, merupakan inti dari DSDM, yang terdiri dari 5 sub tahap yaitu:

a. Studi kelayakan

untuk menilai kelayakan suatu sistem informasi untuk dikembangkan (kelayakan secara ekonomis, teknis, teknologi, dan lainnya) dan menilai apakah DSDM layak digunakan sebagai metodologi untuk mengembangkan sistem informasi yang dibutuhkan.

b. Studi tentang Bisnis

Dalam tahapan pengembangan sistem informasi bersama-sama para pemangku kepentingan lainnya berusaha memahami kebutuhan bisnis. Kebutuhan dimaksud adalah proses-proses bisnis yang relevan, rasionalitas dibalik prosesproses bisnis tersebut,dan kebutuhan informasi tiap-tiap proses bisnis.

c. Perulangan Pemodelan fungsional

Rancangan fungsi utama sistem informasi beserta purwa rupa dibangun dalam tahapan ini.

d. Perulangan Perancangan dan Pengembangan Sistem Informasi

Pada tahapan ini, aplikasi sistem informasi yang dikembangkan sudah siap digunakan oleh pengguna. Aplikasi tersebut harus sudah memiliki kriteria minimal untuk dapat digunakan.

\section{e. Implementasi}

Tahapan ini merupakan saat sistem informasi lama dihentikan dan digantikan oleh sistem informasi terbaru.

3. Setelah proyek yaitu memastikan sistem berjalan secara efektif dan efisien. Hal ini diwujudkan dengan perawatan, peningkatan dan perbaikan sesuai prinsip-prinsip DSDM. Perawatan dapat dilihat sebagai usaha meneruskan pengembangan berdasarkan sifat alami DSDM, yaitu perulangan dan pertambahan.

\subsection{Monitoring}

Menurut Peraturan Pemerintah Nomor 39 Tahun 2006, monitoring adalah kegiatan pengamatan keadaan atau kondisi, termasuk juga perilaku atau kegiatan tertentu yang bertujuan agar semua data masukan atau informasi yang diperoleh dari hasil pengamatan dapat menjadi landasan dalam mengambil keputusan tindakan selanjutnya. Tindakan diperlukan, jika hasil pengamatan menunjukan adalnya hal atau kondisi yang tidak sesuai dengan yang direncanakan semula. Monitoring, bertujuan untuk mengamati/mengetahui perkembangan dan kemajuan, identifikasi dan permasalahan serta antisipasinya/upaya pemecahannya [5].

\subsection{Antropometri}

Antropometri adalah ukuran tubuh manusia. Pengukuran menggunakan metode ini dilakukan karena manusia mengalami pertumbuhan dan perkembangan. Pertumbuhan mencakup perubahan besar, jumlah, ukuran dan fungsi sel, jaringan, organ tingkat individu yang diukur dengan ukuran panjang, berat, umur tulang dan keseimbangan metabolik. Sedangkn perkembangan adalah bertambahnya kemampuan dalam struktur dan fungsi tubuh yang lebih kompleks dalam pola yang teratur dan dapat diramalkan. Pertumbuhan dan perkembangan dapat dipengaruhi oleh faktor internal (genetik) dan faktor eksternal/lingkungan. [3]

\subsection{Unified Modelling Language (UML)}

Salah satu bentuk penggambaran cara kerja sistem adalah dengan pemodelan. Alat pemodelan yang sering digunakan yaitu Unified Modelling Language (UML). UML adalah salah satu alat bantu yang sangat handal di dunia pengembangan sistem yang berorientasi objek. Hal ini disebabkan karena UML menyediakan bahasa pemodelan visual yang memungkinkan bagi pengembang sistem untuk membuat cetak biru atas visi mereka dalam bentuk yang baku, mudah dimengerti serta dilengkapi dengan mekanisme yang efektif untuk berbagi (sharing) dan mengkomunikasikan rancangan mereka dengan yang lain" [6].

\subsection{Status Gizi}

Status gizi adalah keadaan tubuh manusia sebagai akibat konsumsi makanan dan pengguaan zat-zat gizi. Adapun kategori dari status gizi dibedakan menjadi tiga, yaitu gizi lebih, gizi baik, dan gizi kurang. Baik buruknya status gizi manusia dipengaruhi oleh 2 hal pokok yaitu konsumsi makanan dan keadaan kesehatan tubuh atau infeksi. Dalam ilmu gizi, status gizi lebih dan status gizi kurang disebut sebagai malnutrisi, yakni suatu keadaan patologis akibat kekurangan atau kelebihan secara relatif ataupun absolut satu atau lebih zat gizi [3].

\subsection{Posyandu}

Posyandu merupakan kependekan dari pos pelayanan terpadu, sebuah gerakan sosial swadaya yang diselenggarakan dari, oleh, dan untuk rakyat. Dalam penyelenggaraannya, tim peyelenggara posyandu dibimbing dan diawasi langsung oleh petugas kesehatan. 
Sedangkan, tujuan utama penyelenggaraan posyandu adalah memberikan layanan kesehatan masyarakat secara swadaya [2].

\subsection{CodeIgniter}

Web framework adalah gabungan dari komponen (atau library) dan konsep desaign patter. Web framework adalah framework software yang didesain secara khusus untuk mendukung sebuah proses pengembangan aplikasi web. CodeIgniter adalah salah satu web framework yang digunakan untuk menggembangkan aplikasi web dengan menggunakan bahasa pemrograman PHP. CodeIgniter banyak dimanfaatkan oleh para web developer untuk mengembangkan suatu website atau aplikasi [5]. CodeIgniter (CI) juga adalah framework pengembangan aplikasi (Aplication Development Framework) dengan menggunakan PHP, susatu kerangka untuk bekerja atau membuatan program dengan menggunakan PHP yang lebih sistematis.[9]

\subsection{Penelitian Terdahulu}

Selain menggunakan dasar teori tekstual, penelitian ini juga mempelajari penelitian-penelitian terdahulu mengenai status gizi balita.

Penelitian pertama adalah penelitian yang dilakukan oleh Rati Dwi Sanitari dkk, dengan judul Sistem Monitoring Tumbuh Kembang Anak Usia 0-5 Tahun Berbasis Android[7]. Sistem monitoring pada penelitan ini menampilkan hasil klasifikasi perkembangan anak beserta solusi dan nilai presentase dari hasil klasifikasi.

Penelitian kedua adalah penelitian dari Mega Orina Fitri dalam penelitian berjudul "Aplikasi Monitoring Perkembangan Status Gizi Anak dan Balita secara digital dengan metode Antropometri Berbasis Android" [4]. Fokus dari penelitian ini adalah dapat membantu angka kematian bayi kurang gizi. Fitur yang menonjol dalam penelitian ini adalah adanya grafik perkembangan bayi dan balita.

Penelitian terakhir yang menjadi rujukan adalah penelitian dari Imam Sholeh $M$, dengan judul "Pengembangan Aplikasi Posyandu Berbasis Web" [1] Penelitian ini menghasilkan aplikasi berbasis web menggunakan php dan mysql. Aplikasi ini menghasilkan informasi hasil kegiatan penimbangan balita di posyandu.

\section{METODE PENGUMPULAN DATA}

Untuk mendapatkan informasi dan mengumpulkan data yang diperlukan dalam pengumpulan data menggunakan teknik sebagai berikut :

\section{Studi Pustaka (Library Research)}

Merupakan usaha yang dilakukan oleh penulis untuk menghimpun informasi yang relevan dengan topik dan masalah yang akan diteliti. Informasi itu didapat dan diperoleh dari buku-buku ilmiah, laporan penilitian, karangan ilmiah, peraturan-peraturan, ketetapan-ketetapan dan sumber-sumber tertulis baik tercetak maupun elektronik serta internet.
2. Studi Lapangan (Field Research)

Yaitu pengumpulan data yang dilakukan pada objek penelitian langsung dalam hal ini adalah pada petugas kesehatan yang bertugas di posyandu Seruni 11 untuk melakukan observasi dan wawancara sehingga dapat diperoleh informasi yang menyeluruh, tepat dan benar.

3. Observasi adalah metode yang dilakukan untuk mengidentifikasi data yang dilakukan secara sistematis baik secara langsung atau tidak langsung yang diteliti serta mengambil data-data penelitian secara lengkap.

4. Wawancara adalah pengumpulan data dan informasi yang diperoleh dari salah seorang bidan untuk memeperoleh data yang dibutuhkan untuk membangun sistem dimana bidan tersebut mempunyai buku panduan yang isinya rumus untuk menghitung status gizi pada balita.

\section{HASIL DAN PEMBAHASAN}

\subsection{Penerapan Dynamic System Development Method (DSDM) \\ 1. Sebelum Proyek}

Pada tahapan sebelum proyek ini sebelum proyek dilakukan, terlebih dahulu peneliti melakukan:

a. Mengidentifikasi permasalahan yang terjadi pada posyandu seruni 11 seperti yang telah terurai pada rumusan masalah.

b. Menyiapkan pembiayaan proyek agar biaya proyek terpenuhi.

c. Mengajukan permohonan yang berisi pengajuan perizinan tempat untuk penelitian, narasumber dan pengambilan data yang diperlukan.

\section{Siklus Hidup Proyek}

\section{a. Studi Kelayakan}

Tahapan studi kelayakan berisi mengenai persiapan di lingkungan internal pengembang, diantaranya:

1) Menganalisa objek penelitian

Menganalisis terhadap penggunaan metode DSDM dalam pengembangan sistem informasi yang akan dibangun pada objek yang diteliti.

2) Kebutuhan sistem

Mempersiapkan software dan hardware penunjang sistem yang dibuat untuk menunjang kebutuhan dalam pembuatan sistem. Kebutuhan yang dibutuhkan dalam pembangunan sistem ini diantaranya menganalisa dan mempersiapkan spesifikasi Hardware di antaranya diantaranya adalah:

- Intel Core I3 5010U. 2.1 GHz

- RAM 4 GB

- Harddisk $500 \mathrm{~GB}$

- Printer Cannon E410 
Spesifikasi Software

- Windows 8.0

- Php

- MySq1

- PhpMyAdmin

- Browser Mozila firefox, Internet Eksplore

3) Pencapaian yang dituju

Tujuan yang ingin dicapai dari adanya sistem aplikasi ini adalah untuk menjadikan sistem ini sebagai sarana bagi orang tua dan petugas posyandu Seruni 11 untuk memonitoring status gizi balita.

\section{b. Studi Tentang Bisnis}

Keterlibatan narasumber yakni ketua posyandu beserta anggota yang akan menjadi admin pada aplikasi yang akan dibangun dan juga peneliti agar dapat mensinkronkan pembangunan aplikasi yang diajukan agar aplikasi yang akan dibangun dapat bermanfaat dan layak untuk dijalankan dengan keuntungan yang akan dihasilkan. Dengan mengetahui keperluan yang diperlukan oleh narasumber seperti pembangunan aplikasi yang terdiri dari penyimpanan data balita maupun data hasil pengukuran berat badan balita yang akan disimpan dengan penyimpanan database agar data balita tidak mudah hilang, dan untuk memberi kemudahan bagi anggota posyandu serta orang tua balita untuk mengetahui status gizi balita dengan mudah sehingga menguntungkan pengguna aplikasi ini untuk mengetahui status gizi balita dengan cepat dan memperpendek waktu penentuan status gizi balita.

Mendefinisikan kebutuhan fungsional dan operasional sistem dengan mendefinisikan sekenario penggunaan sistem. Dari analisis kebutuhan sistem, maka use case diagram yang diusulkan peneliti untuk sistem monitoring status gizi balita adalah sebagai berikut:

\section{1). Use Case Diagram Admin Posyandu}

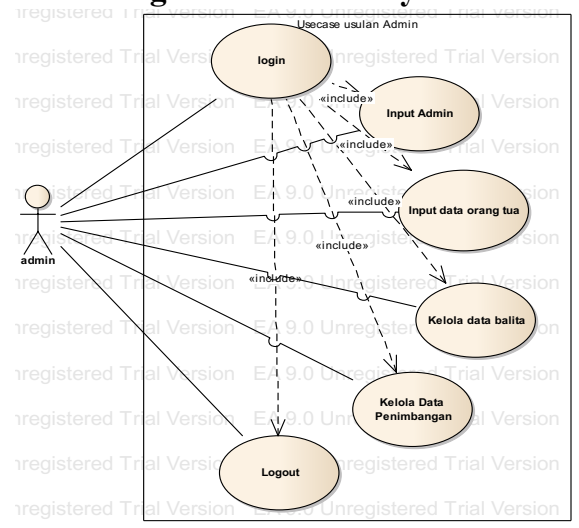

Gambar 2. Use case Diagram Admin Posyandu

\section{Skenario}

Dalam aplikasi ini dijabarkan skenario sistem pada admin yang di butuhkan sesuai dengan use case sistem aplikasi yang dibangun, yang terdiri dari use case scenario log in, input admin, input data orang tua, kelola data balita, kelola data penimbangan dan log out.

\section{2). Use Case Diagram User Posyandu}

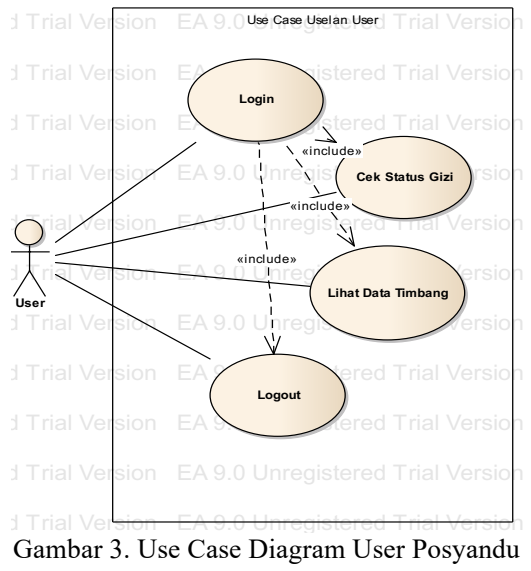

\section{Skenario}

Dalam aplikasi ini dijabarkan skenario sistem pada user atau orang tua yang di butuhkan sesuai dengan use case sistem aplikasi yang dibangun, yang terdiri dari use case scenario $\log$ in, cek status gizi, melihat data timbang dan $\log$ out.

\section{c. Perulangan Pemodelan}

Pada tahapan ini mulai merancang fungsi utama sistem informasi yang akan di bangun. Merancang purwa rupa sistem antar muka tampilan program yang akan di buat. Berikut merupakan menu-menu yang akan dirancang.

1). Rancangan Menu Admin

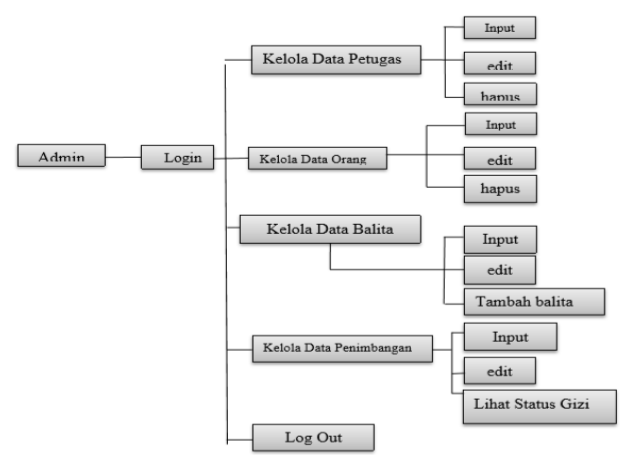

Gambar 4. Rancangan Menu Admin

2). Rancangan Menu Orang Tua

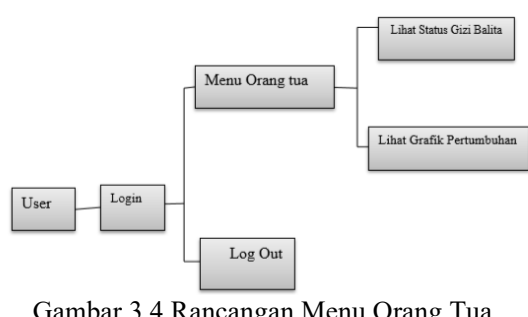




\section{d. Perulangan Perencanaan dan Pengembangan Sistem}

Pada tahapan ini merancang gambaran menu sistem yang akan di kembangkan. Penggambaran pada menumenu form input yang akan di tampilkan pada menu admin maupun menu orang tua balita.

\section{1) Rancangan Form input Login}

Form input login digunakan untuk user ataupun admin untuk masuk ke aplikasi monitoring status gizi balita agar dapat masuk ke tahap berikutnya.

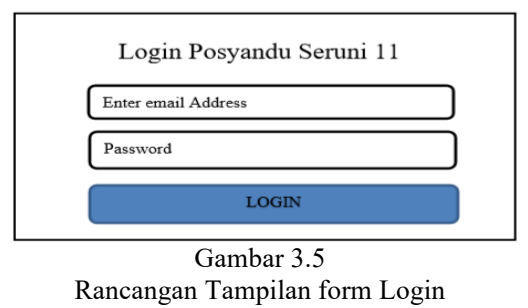

2) Rancangan Menu Input Admin

Menu utama admin digunakan sebagai halaman utama admin untuk mengakses web ini. Pada halaman ini menampilkan menu yang dapat mengakses ke semua halaman seperti menu kelola data petugas, kelola data orang tua, dan kelola data penimbangan.

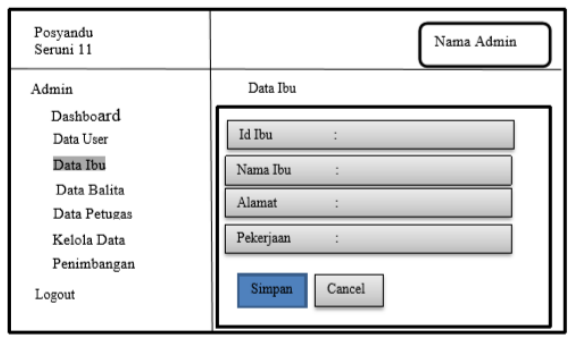

Gambar 3.6

Rancangan Menu Input Admin

3) Rancangan Menu Output Admin

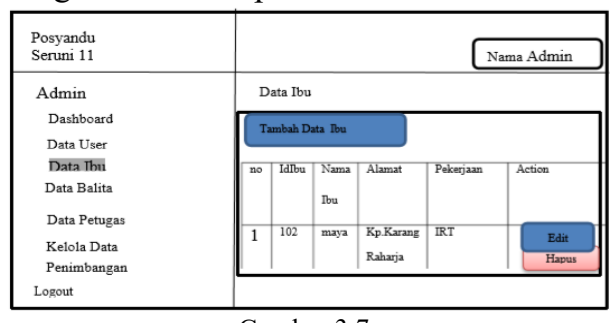

Gambar 3.7

Rancangan Menu Ouput Admin

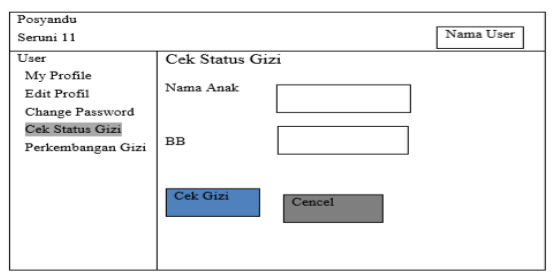

Gambar 3.8

Rancangan Menu Input User

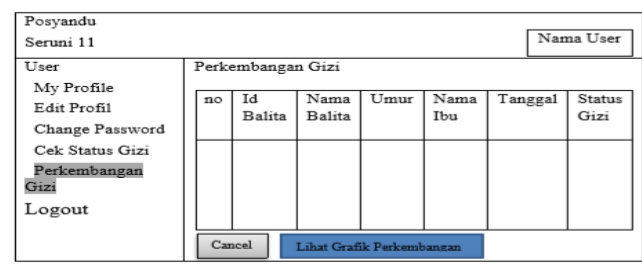

Gambar 3.8

Rancangan Menu Output User

\section{e. Implementasi}

Pada tahapan implementasi ini dijelaskan mengenai perancangan database yang akan digunakan dalam sistem monitoring status gizi di Posyandu Seruni 11 dengan cara penyusunan data dan membuat struktur tabel yang dibutuhkan menyimpan data-data yang diperlukan.

Sistem yang dibuat dapat memonitoring status gizi balita yang telah mengikuti kegiatan penimbangan berat badan balita setiap satu bulan sekali dengan ketentuan balita dan orang tua telah terdaftar pada posyandu Seruni 11. Implementasi menggunakan codeigniter didapatkan beberapa halaman web sebagai berikut:

1) Form Login

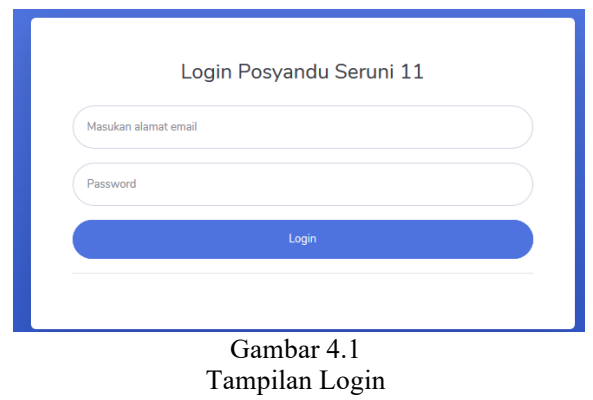

Login ini memiliki fungsi sebagai pintu atau tampilan awal untuk masuk dalam ke dalam sistem. Dengan menginput alamat email dan password maka sistem akan menampilakan tampilan User atau Admin, sesuai status email yang telah terdaftar

\section{2) Menu Admin}

Jika email yang di input pada form login merupakan email yang berstatus admin maka sistem akan menampilkan menu Admin. Dalam menu ini Admin dapat menginput data user, data orang tua dan data balita, data petugas serta mengelola data penimbangan balita.
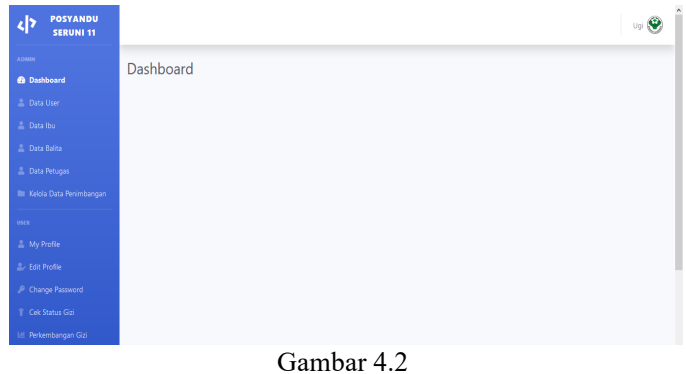

Tampilan Menu admin 


\section{3) Tampilan Menu Kelola Data Penimbangan}

Menu ini di pergunakan oleh petugas atau admin posyandu Seruni 11 untuk menginput data hasil penimbangan dengan terlebih dahulu menginput id balita dan berat badannya maka kondisi gizi balita dapat di ketahui dengan mudah.Laporan data hasil penimbangan pertiap bulan balita dapat di cetak pada tampilan button cetak laporan.

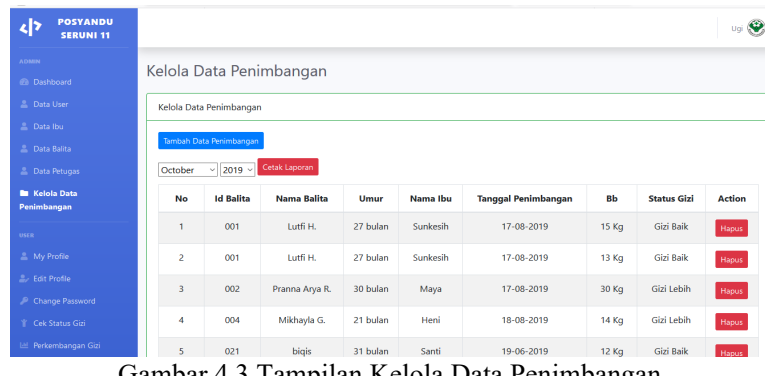

Gambar 4.3 Tampilan Kelola Data Penimbangan

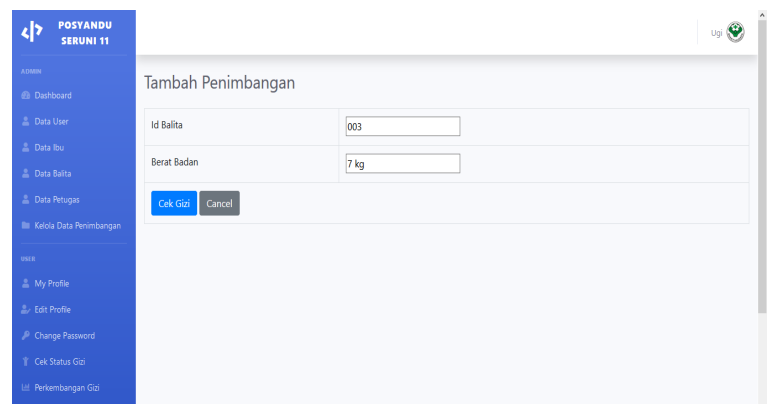

Gambar 4.4 Tampilan Tambah Data Penimbangan

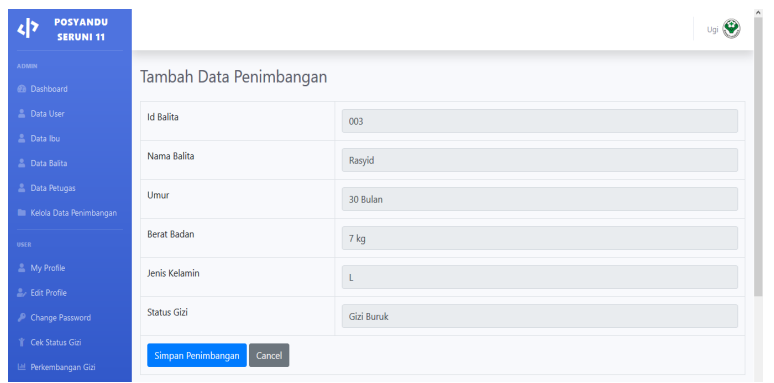

Gambar 4.5 Tampilan Status Gizi Balita

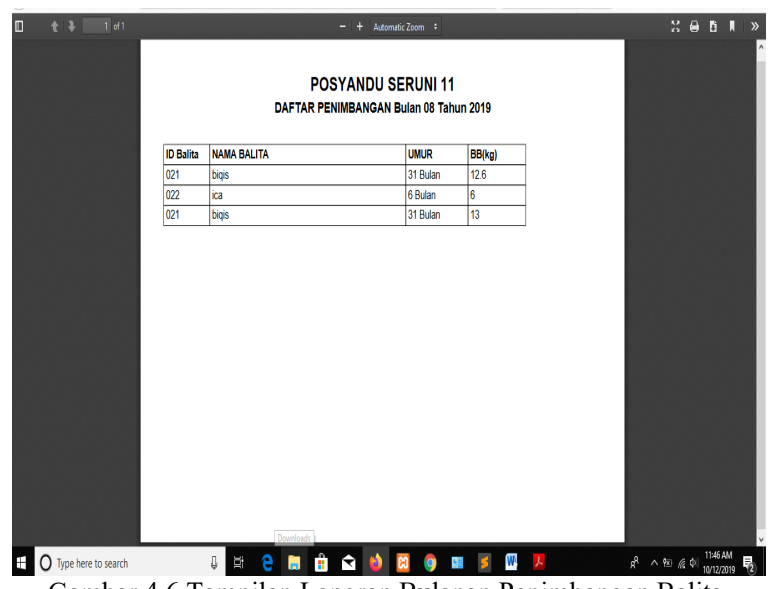

Gambar 4.6 Tampilan Laporan Bulanan Penimbangan Balita
4) Menu User atau Orang Tua Balita

Jika email yang di input pada form login merupakan email yang berstatus user atau orang tua balita maka sistem akan menampilkan menu User. Dalam menu ini orang tua dapat melihat status gizi balita serta perkembangan berat badan balita.

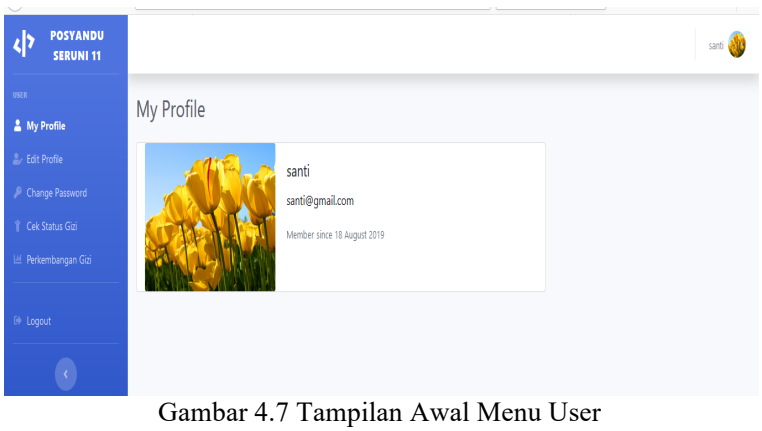

Untuk melihat status gizi pada balita, orang tua dapat memilih menu cek status gizi dan memilih nama balita jika memiliki balita lebih dari satu lalu menginput berat badan balitanya.
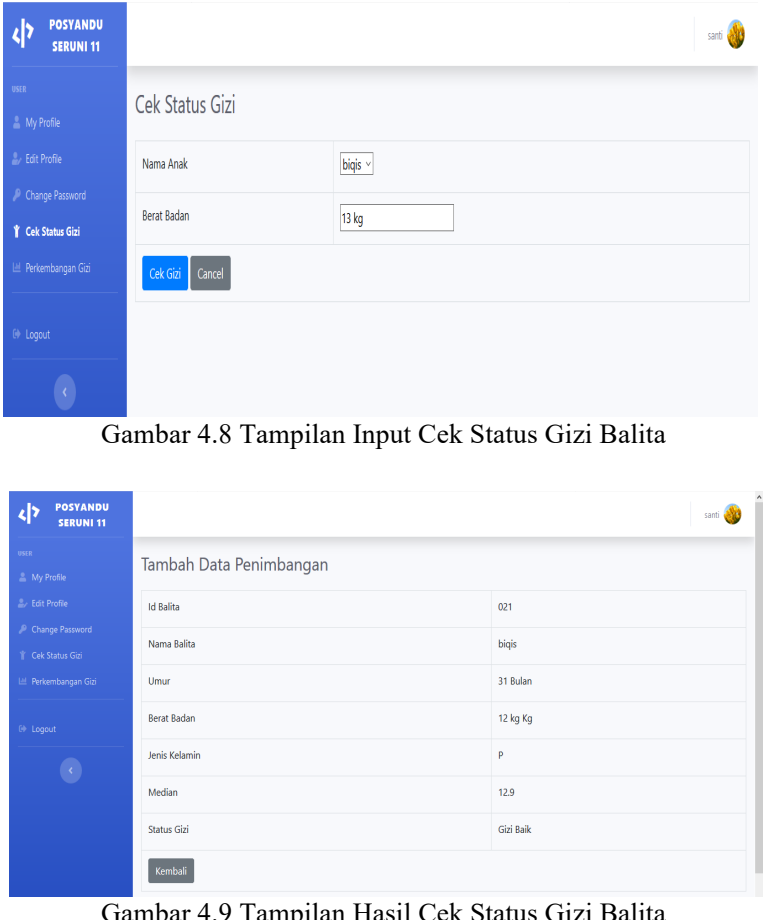

Untuk melihat perkembangan gizi balita maka dapat membuka button perkembangan gizi yang didalamnya terdapat data balita serta dapat melihat grafik penimbangan berat badan balita. 


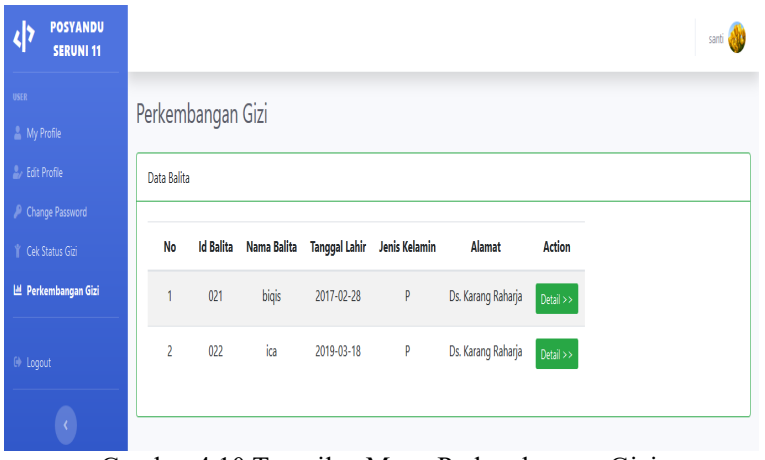

Gambar 4.10 Tampilan Menu Perkembangan Gizi

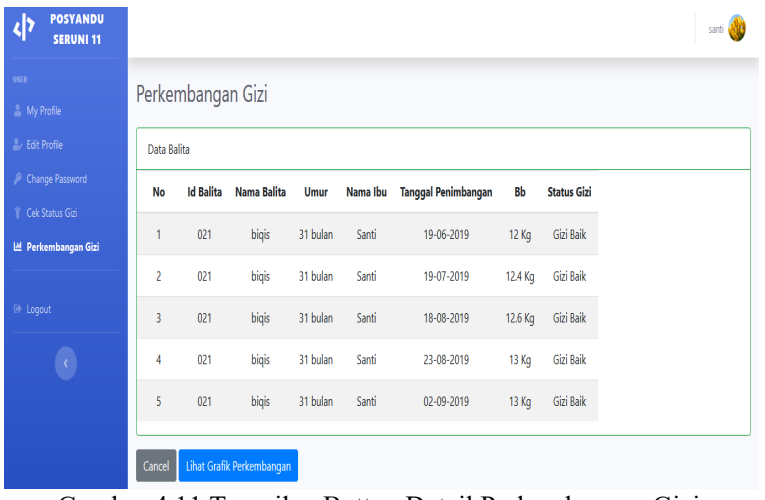

Gambar 4.11 Tampilan Button Detail Perkembangan Gizi

Grafik penimbangan ini menunjukan hasil penimbangan berat badan balita pada tiap bulannya.

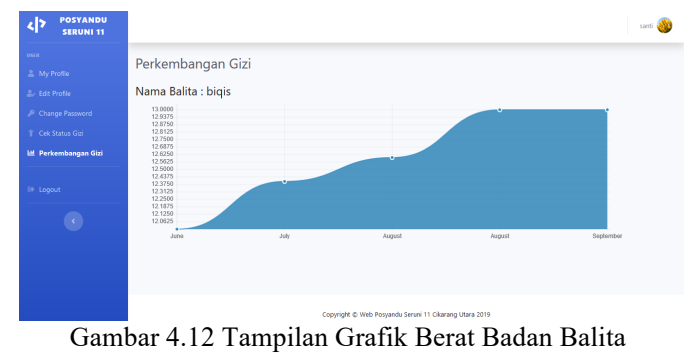

\section{Setelah Proyek}

Untuk memastikan sistem berjalan sesuai dengan harapan maka di perlukannya pengujian sistem yang telah di bangun. Pengujian sistem ini meliputi verifikasi kinerja system yang berisi tentang pengujian sistem yang dibuat apakah sudah bekerja dengan baik atau belum dan validasi penggunaan system. Dalam pengujian kelayakan sistem ini menggunakan tahapan uji kelayakan kuesioner. Kuisioner merupakan daftar pertanyaan yang diajukan kepada responden untuk mencari jawaban dari permasalahan yang diteliti.

\section{KESIMPULAN}

Dari hasil penelitian dan penerapan metode Dynamic System Development Method (DSDM) pada rancang bangun monitoring status gizi balita dengan menggunakan framework CodeIgniter, maka dapat diperoleh kesimpulan berdasarkan hasil implementasi dan pengujian yang dilakukan penulis selama proses penelitian sebagai berikut :
1. Sistem yang dibuat dapat menjadi solusi meminimalisir kehilangan data balita dengan sistem penyimpanan database.

2. Sistem yang dibuat dapat mempermudah petugas dan orang tua balita untuk mengetahui status gizi balita dengan cepat dengan acuan Berat Badan menurut Umur $(\mathrm{BB} / \mathrm{U})$

3. Dengan penyimpanan yang tersistematis maka sistem yang dibuat dapat mempercepat proses pencarian data balita.

\section{DAFTAR PUSTAKA}

[1] Iman Soleh M, Pengembangan Aplikasi Posyandu Berbasis Web, Jurnal Evolusi, 2017

[2] Kurnia, R. POSYANDU : Pedoman Pelaksanaan Posyandu, Kesehatan Masyarakat Desa dan Kelurahan, Bee Media Pustaka, Jakarta Timur, 2019

[3] Mardalena, I. Dasar-Dasar Ilmu Gizi dalam Keperawatan, PUSTAKA BARU PRESS, klaten, 2017

[4] Mega Orina Fitri, "Aplikasi Monitoring Perkembangan Status Gizi Anak dan Balita secara Digital dengan Metode Antropometri Berbasis Android”, Jurnal Instek, Makassar, 2017.

[5] Mulyono dan Yumari. Strategi Monitoring dan Evaluasi Pelaksanaan anggaran, Deepublish, Yogyakarta, 2017

[6] Munawar, Analisis Perancangan Sistem Berorientasi Objek dengan UML, Informatika Bandung, Bandung, 2018

[7] Rati Dwi Sanitari, "Sistem Monitoring Tumbuh Kembang Anak usia 0-5 Tahun Berbasis Android”, Jurnal Rekursif, Bengkulu, 2017.

[8] Sarosa, S. Metodologi Pengembangan Sistem Informasi, Indeks Jakarta Jakarta, 2017

[9] Sidik, Membangun Pemrograman Berbasis WEB dengan Berbagai Kemudahan \& Fasilitas CodeIgniter 3, Informatika Bandung, Bandung, 2018

[10] Sophan, M. K. Pengembangan Aplikasi Web Menggunakan Codeigniter Konsep dan Inplementasi, Deepublish, Yogyakarta, 2016 